УДК 94+215(571.5)

ЦЫРЕМПИЛОВА Ирина Семеновна - доктор исторических наук, доцент; проректор по научной работе Восточно-Сибирского государственного института культуры (670031, Россия, Республика Бурятия, г. Улан-Удэ, ул. Терешковой, 1; irina161073@таі..ru)

\title{
АНТИРЕЛИГИОЗНАЯ АГИТАЦИЯ И ПРОПАГАНДА В 1920-е ГОДЫ: ФОРМЫ, ОПЫТ И ЭФФЕКТИВНОСТЬ (на материалах Байкальского региона)
}

\begin{abstract}
Аннотация. В статье на основе документов государственных архивов Республики Бурятия, Иркутской области и Забайкальского края рассматривается становление и развитие антирелигиозной агитации и пропаганды в 1920-е гг. На конкретных примерах подробно показано разнообразие форм и методов этой работы - от лекций, диспутов, митингов, шествий, демонстраций, спектаклей и карнавалов до антирелигиозных дней, недель, акций, кампаний и др. Автор рассматривает сложности организационного и кадрового обеспечения антирелигиозной работы.
\end{abstract}

Ключевые слова: антирелигиозная политика, антирелигиозная агитация и пропаганда, Байкальский регион, церковь, верующие, безбожники

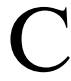
Свременная исследовательская ситуация характеризуется изменением подходов к изучению различных аспектов антирелигиозной политики советского государства, среди которых одно из ключевых мест занимает агитационно-пропагандистская работа. Охват и результаты этой работы, ее значимость как важнейшего средства воспитания человека новой формации, разнообразие форм и методов, региональная специфика требуют специального изучения. Достижения отечественной историографии, привлечение широкого круга источников, необходимость преодоления сложившихся стереотипных представлений о способах проведения агитации и пропаганды позволят проанализировать опыт антирелигиозных практик в 1920-е гг. на территории Байкальского региона.

Основные установки по вопросам организации и проведения антирелигиозной агитации и пропаганды принимались на самом высоком партийно-государственном уровне. Созданный в 1920 г. отдел агитации и пропаганды (агитпропотдел) ЦК РКП(б) совместно с Главполитпросветом должны были вести антирелигиозную и естественнонаучную пропаганду среди широких масс населения. Решением Х съезда РКП(б) (1921 г.) предусматривалось создание сети агитационно-пропагандистских отделов (АПО) «при всех губкомах, областкомах, бюро ЦК и крупных парткомах» 1 . Вслед за постановлением пленума ЦК РКП(б) был принят циркуляр «О постановке антирелигиозной пропаганды» $(1922 \text { г. })^{2}$, который был разослан на места.

События Гражданской войны и перманентная смена власти на территории Байкальского региона обусловили трудности государственного строительства в начале 1920-х гг. Несмотря на это, агитационно-пропагандистские

1 Десятый съезд РКП(б). Март 1921. Стенографический отчет. М.: Госполитиздат. 1963. C. 597.

2 Конфессиональная политика советского государства. 1917-1991 г2.: документы и материалы: в 6 т. Т. 1: в 4 кн.: 1917-1924 гг. Кн. 1: Центральные руководящие органы РКП(б): идеология вероисповедной политики и практика антирелигиозной пропаганды. М.: Политическая энциклопедия. 2017. С. 312. 
отделы были созданы в структуре Иркутского губкома в апреле 1920 г., БурятМонгольского обкома, Забайкальского губкома - в 1921 г. В первые годы деятельность региональных АПО была направлена на разъяснительную работу среди населения о нововведениях: продовольственном налоге, нэпе, кампании помощи голодающим Поволжья и др. Основные трудности были связаны с кадровым обеспечением данного направления работы - отсутствием аппарата, перегруженностью, нехваткой квалифицированных сотрудников, что зачастую приводило к выполнению работы по совместительству. Следует отметить, что антирелигиозная агитация и пропаганда входили также в задачи Наркомпроса, Политпросвета, женотделов, комсомола и др. ${ }^{1}$

Борьба на идеологическом фронте, или антирелигиозная пропаганда, целью которой являлось стремление «выбить» из сознания людей «религиозный дурман» и освободить его для новой - социалистической - идеологии, являлась важным направлением государственной политики. Антирелигиозная пропаганда была сконцентрирована в комплексе социокультурных мероприятий, затрагивающих все стороны жизни населения. «Выдержанная линия по внедрению безбожия прежде всего в семье, а затем и в окружающем населении» проводилась в партийных ячейках («есть случаи и очень нередки, когда коммунисты имеют иконы, молятся богу для “показа”»), в сельских органах («работа по внедрению культурных навыков в сельское хозяйство»), в избах-читальнях, красных уголках, школах («умело поставленное антирелигиозное воспитание», «объяснение явлений природы в противовес силе бога») и др. ${ }^{2}$

Формы антирелигиозной агитации и пропаганды на местах нередко носили жесткий, оскорбительный для верующих характер. Уровень проводимых мероприятий также был недостаточно высок: в дело борьбы с религией были втянуты во многом необразованные люди, имевшие скудные представления не только о религии, но и о развитии культуры в целом. К распространенным в эти годы формам борьбы с религией следует отнести различного рода митинги, демонстрации, карнавалы, шествия с карикатурами на богов и духовенство, антирелигиозные дни, недели, комсомольское рождество, комсомольская пасха и т.д. Атеисты дискутировали со служителями культа, читали лекции с демонстрацией опытов, разоблачающих религиозные «чудеса». Создавались новые праздники и обряды, призванные вытеснить религиозные ритуалы, ставились антирелигиозные спектакли.

В докладе заведующего АПО Иркутского губкома РКП(б) Ольхового на совещании заведующих агитпропами уездных и районных комитетов Иркутской губернии, состоявшемся 17 июля 1922 г., разъяснялись основные задачи антирелигиозной пропаганды. Докладчик отмечал: «...наша задача прежде выяснить, что такое религия, а потом уже создавать новое миросозерцание. Не только разрушать, но и параллельно создавать. Мы не должны догматически заявлять, что нет Бога, нужно просто показать, что все совершается без него, он нигде себя не проявляет, если не проявляет, значит его и нет. «..> Нам весьма важно дискредитировать попа, но прежде всего необходимо покончить с религией, а потом с попом» 3 . В качестве рекомендаций указывалось на необходимость познакомиться с философским обоснованием материализма, проштудировать труды Маркса, Энгельса, Фейербаха и др. О достаточно высоком уровне методической подготовки докладчика свидетельствует и используемый

${ }_{1}^{1}$ Государственный архив Республики Бурятия (ГАРБ). Ф. П-1. ОП. 1. Д. 70. Л. 3-4.

2 ГАРБ. Ф. П-1. ОП. 1. Д. 1321. Л. 12-14.

3 Государственный архив новейшей истории Иркутской области (ГАНИИО). Ф. 1. Оп. 1. Д. 1316. Л. 50-51. 
им понятийный аппарат («имманентный способ», «метод исторического материализма», персональная агитация и др.).

Массовые кампании антирелигиозных праздников включали в себя комплекс различных мероприятий, которые проводились в течение одного-двух месяцев. Так, в Иркутской губернии празднование комсомольского рождества в декабре 1922 - начале 1923 г. стало новым событием. Для этого был специально разработан и утвержден календарный план: с 15 декабря по 6 января цикл естественнонаучных (происхождение Земли, происхождение жизни на Земле, происхождение человека) и антирелигиозных (происхождение религии и вера в бога, иудейство, христианство и магометанство, сектантство) лекций. Также в этот период на различных площадках должны были быть проведены специальные собрания о значении комсомольского рождества. С 15 декабря при клубах и красных уголках должны быть созданы постоянно действующие кружки безбожников. Большой объем работы приходился на клубные мероприятия: показ антирелигиозных постановок, инсценировок на сюжеты антирелигиозной сатиры, концертные отделения с декламацией юмористических антирелигиозных стихов, воспоминания бывших верующих о разрыве с религией и др. В первый день рождества должно было состоялось шествие, «участники которого по данному в 6 часов вечера сигналу (ракетами) собираются на городскую площадь, откуда уже карнавалом с пением и музыкой двигаются по клубам»1. При этом предлагалось провести сжигание фигур попа и церкви, но затем от этого действа решено было воздержаться [Цыремпилова 2008: 128].

Согласно информационной сводке Иркутского губотдела ГПУ, 6 и 7 января 1923 г. в г. Иркутске была проведена «антирождественская пропаганда, выразившаяся в постановке антирелигиозных инсценировок и в карнавале». В Селенгинском уезде «шествие по городу привлекло массу публики... было зарегистрировано несколько случаев отречения от религии» ${ }^{2}$. Так как «рождественские» мероприятия были проведены в Иркутске и в уездных центрах, то комсомольскую пасху планировалось больше «распространить по уездам» губернии ${ }^{3}$.

В городах и рабочих поселках Забайкальской губернии «в дни еврейской и православной пасхи» 1923 г. был «устроен суд над религией, два раза поставлен живой журнал “Безбожник” , изданы «антирелигиозные лозунги, ходячие рекламы», в государственном театре г. Читы 5 раз была поставлена пьеса «Жрец Тарквиний», в клубах - пьеса «Три Иисуса». Был организован ряд публичных лекций на тему «Сущность пасхи». Кроме того, «комсомолом был устроен “комсомольский сейдер” и карнавал. В общей сложности мероприятия этой кампании посетило более 10 тыс. человек» 4 . Необходимо отметить, что со стороны центра осуществлялось методическое обеспечение антирелигиозной работы, региональные АПО оформляли заказы на получение специальной литературы из издательства «Атеист». Так, в 1922 г. Иркутский губком сделал заказ на пьесу «Жрец Тарквиний», которая «горячо рекомендуется для постановки в рабоче-крестьянских театрах». Эта трагедия в 3 действиях должна была иметь «огромное агитационное значение в деле борьбы с религиозными суевериями и дискредитации церковников». К пьесе прилагались рисунки и схемы декораций, составлены объяснения в части режиссерской, музыкальной и художественной постановки. Согласно переписке, 1-е издание этой пьесы

\footnotetext{
${ }^{1}$ ГАНИИО. Ф. 1. Оп. 1. Д. 1521. Л. 10.

2 ГАНИИО. Ф. 1. ОП. 1. Д. 1076. Л. 35.

3 ГАНИИО. Ф. 1. ОП. 1. Д. 1422. Л. 46(об).

4 Государственный архив Забайкальского края (ГАЗК). Ф. П-81. Оп. 1. Д. 438. Л. 87-88.
} 
разошлось быстро, стоимость 2-го издания за 1 экземпляр составляла 500 тыс. руб., 3-го издания - уже 350 тыс. руб.; заказ можно было сделать по телеграфу1.

Первый опыт организованной антирелигиозной пропаганды отмечен неудачными попытками проведения массовых и самодеятельных кампаний и разовых акций, которые на местах проводились некомпетентными кадрами. Это вызывало у населения только недоверие к органам власти и стало объективной причиной изменения тактики: от открытой войны с церковью было решено перейти к систематической антирелигиозной пропаганде. Как отмечалось в тезисах о методах и формах антирелигиозной пропаганды по Верхнеудинскому уезду, «от кустарщины, от кампанейских наскоков, от распыления сил в антирелигиозной пропаганде нужно отказаться, нужно окончательно перейти к длительной систематической и углубленной пропаганде под руководством партии» ${ }^{2}$.

Забайкальский губком РКП(б) обратился на места с особым циркуляром, в котором отмечалось, что при проведении агитации и пропаганды ни в коем случае не следует оскорблять чувства верующих, необходимо на основе научных данных и примеров из жизни их «убеждать во лжи религиозных мировоззрений» 3.28 июня 1923 г. президиум Иркутского губкома РКП(б) принял решение: «Агитпропу губкома дать на места директиву об осторожном отношении к религиозным убеждениям крестьян и рабочих» 4 .

К стратегическому направлению следует отнести также антирелигиозную работу среди членов партии. Так, постановление пленума ЦК РКП(б) «Об отношении к нарушениям пункта 13 Программы РКП(б) и о постановке антирелигиозной пропаганды» (26 июля 1921 г.) содержало требование к членам партии прекратить связь с церковью какого бы то ни было вероисповедания и исключить их из партии, если они этой связи не прекращают. В данном постановлении по отношению к членам партии или вступающим в нее из числа крестьян и рабочих, которые «колеблются и допускают вынужденную необходимость выполнения тех или иных церковных обрядов», предусматривался особый подход. Они могли быть приняты в кандидаты и в члены партии после соответствующего с их стороны заявления. При этом допускалось в отдельных случаях в виде исключения участие в партии верующих, если они «своей революционной борьбой и работой в пользу революции, ее защитой в опаснейшие моменты, доказывали свою преданность по отношению к коммунизму» 5 .

Забайкальский губком партии обратился с особым циркуляром, в котором подчеркивалось: «...мы не можем не бороться против каких бы то ни было религий: христианской или магометанской, буддийской или иудейской».

Иркутский губком в ходе чистки партийных рядов с 1 января по 1 июля 1923 г. исключил из партии 226 чел., большая часть которых были вычищены «за проявление религиозности» 6 . Волостной комитет РКП(б) Тулунского уезда в мае 1924 г. докладывал в губком, что «все члены и кандидаты имеют в своих квартирах иконы», иконы были изъяты у 5 членов партии ${ }^{7}$. В ноябре 1924 г. рабочие Усольского соляного завода Питиримов и Рогов были исключены из

1 ГАНИИО. Ф.1. ОП.1. Д.1574. Л.7-8.

2 ГАРБ. Ф. П-1. ОП. 1. Д. 949. Л. 61.

3 ГАЗК. Ф. П-81. ОП. 1. Д. 379. Л. 10.

4 ГАНИИО. Ф. 1. ОП. 1. Д. 1435. Л. 26.

5 Конфессиональная политика советского государства. 1917-1991 г2.: документы и материалы: в 6 т. Т. 1: в 4 кн.: 1917-1924 гг. Кн. 1: Центральные руководящие органы РКП(б): идеология вероисповедной политики и практика антирелигиозной пропаганды. М.: Политическая энциклопедия. 2017. С. 151-153.

6 ГАНИИО. Ф. 1. ОП. 1. Д. 1438. Л. 131.

7 ГАНИИО. Ф. 1. ОП. 1. Д. 1939. Л. 14а. 
партии «за религиозные обряды и убеждения»: оба крестили детей в церкви, а Рогов «вел агитацию, что у него ребенок до крещения был больной, а после выздоровел» 1 . Однако следует отметить, что «число исключенных по причине религиозности было небольшим по сравнению с теми, кто нарушал партдисциплину или пьянствовал» [Готовщик 2011: 87].

Изменение тактики привело к пересмотру форм и методов антирелигиозной агитации. Теперь в качестве приоритетных были определены агрономическая пропаганда через естественнонаучные сельскохозяйственные кружки, ликвидация неграмотности в созданных ликбезах, избах-читальнях, внедрение системы здоровьесберегающих и санитарных мероприятий, культурно-просветительская работа, досуговые и бытовые практики и т.д. Особое значение уделялось образовательному процессу, в т.ч. включению антирелигиозной пропаганды в школьные программы.

Так, в плане работы Тулунского укома на октябрь 1924 г. - апрель 1925 г. в объединенном разделе «Агропропаганда и антирелигиозная пропаганда» было указано проведение периодических лекций и бесед по вопросам естествознания, использование религиозных праздников (рождество и пасха) в деле пропаганды естественнонаучных и агрономических знаний. Результатом стала организация на территории уезда 4 естественнонаучных кружков, при избахчитальнях - 14 кружков безбожников. В Иркутском уезде за сентябрь-декабрь 1924 г. было проведено 15 «октябрин», в клубах прочитаны 4 лекции (охват составил до 1500 чел.), 15 антирелигиозных вечеров и 2 диспута ${ }^{2}$.

В качестве агитационных форм стали широко использоваться стенгазеты, журналы, плакаты, были организованы кружки ОДГБ (Общество друзей газеты «Безбожник»). К числу новаций можно отнести «антирелигиозный семинарий», приобретение «одной кинофильмы антирелигиозного содержания» ${ }^{3}$, так называемые вечера неразрешенных вопросов, которые, по мнению организаторов, «проходят оживленнее и бывают многолюдными» ${ }^{4}$. При этом было принято решение о нецелесообразности проведения антирелигиозных диспутов в деревне как «формы, не дающей положительных результатов».

С середины 1920-х гг. прямолинейный накал антирелигиозной пропаганды ненадолго был свернут. Директивой Сибирского крайкома ВКП(б) от 19 января 1926 г. категорически запрещалось «допускать проведение неподготовленных, навязываемых антирелигиозных демонстраций и диспутов или таких инсценировок, которые вызывают только недовольство масс, возмущают их» ${ }^{5}$. Однако 25 мая 1928 г. было принято специальное постановление Сибирского крайкома ВКП(б) «Об усилении антирелигиозной пропаганды» [Бакаев 2002: 161].

Во второй половине 1920-х гг. основной объем антирелигиозной агитации стал приходиться на деятельность массовой общественной организации «Союз воинствующих безбожников» (СВБ). Как и по всей стране, созданные антирелигиозные кружки были реорганизованы в организации СВБ. Одним из первых на территории Байкальского региона институционально был оформлен Бурят-Монгольский областной совет безбожников, устав которого был зарегистрирован в центральном совете СБ 27 января 1927 г.; а в 1928 г. в республике насчитывались 23 ячейки общей численностью в 928 чел. 610 марта 1929 г. на конференции был образован Иркутский окружной совет СБ, в который было

\footnotetext{
1 ГАНИИО. Ф. 1. ОП. 1. Д. 2177. Л. 60-61.

2 ГАНИИО. Ф. 1. ОП. 1. Д. 1938. Л. 34(об), 111.

3 ГАНИИО. Ф. 1. ОП. 1. Д. 2062. Л. 13, 59.

4 ГАНИИО. Ф. 1. ОП. 1. Д. 2169. Л. 27(об).

5 ГАНИИО. Ф. 1. ОП. 1. Д. 2462. Л. 119.

6 ГАРБ. Ф. Р-581. ОП. 1. Д. 3. Л. 140. Д. 4. Л. 5.
} 
избрано 25 членов от различных районных и городских советов, военных, образовательных и общественных организаций ${ }^{1}$. Сретенский окружной съезд безбожников, проходивший в феврале 1929 г., констатировал удовлетворительное завершение организационного оформления окружного совета; по округу на 1929 г. действовали 78 ячеек $^{2}$.

Оживление антирелигиозной работы во второй половине $1920-$ х гг. характеризовалось рядом изменений, среди которых можно выделить дифференцированный подход к различным группам населения, анализ деятельности религиозных общин по адаптации к новым условиям, учет накопленного опыта антирелигиозного воспитания. Дифференцированный подход нашел выражение в разработке специальных методов для деревни, среди городского и рабочего населения, национальных меньшинств и т.д., что закреплялось в планах антирелигиозных работ. В условиях городского пространства легче было проводить массовые антирелигиозные кампании, внедрять более активные формы работы, также стали широко использоваться возможности кино, радио, библиотек, музеев и др. В сельской местности эффективными формами атеистической работы продолжала оставаться пропаганда естественнонаучных, сельскохозяйственных, правовых и др. знаний.

Однако, несмотря на принимаемые меры, можно констатировать, что эффективность антирелигиозной работы в середине $1920-$ х гг. была невысокой. Праздничные религиозные традиции и обычаи населения были довольно распространенным явлением. 10 апреля 1925 г. президиум Черемховского райкома ВКП(б) отменил постановление о переносе нерабочих дней пасхи на празднование первого мая. Связано это было с тем, что «железная дорога празднует Пасху и не соглашается в эти дни подавать вагоны для погрузки угля» [Цыремпилова 2008: 162]. В информационных сводках Иркутского губотдела ОГПУ за 1926 г. отмечалось, что большинство населения губернии продолжало отмечать религиозные праздники ${ }^{3}$.

Но к концу 1920-х гг. можно констатировать факты имеющихся «достижений» антирелигиозной агитации среди верующих, особенно среди молодежи. Так, священники Забайкальской епархии в рапортах за 1929 г. сообщали: «Требовались неимоверные усилия в борьбе с внешними влияниями, новыми насаждениями, социализацией, коммунизацией, коллективизацией и машинизацией и всякими другими организациями - профсоюзов, батрачкомов и т.д. ...Главное зло новых веяний для церкви приняли организации комсомолов, кружки безбожников, стенгазеты и кружки пионеров. Вся недозревшая молодежь, падкая на все новшества, очертя голову бросилась в водоворот новой жизни и погрязла в омуте нравственных безобразий». В докладе иерея Троицкосавского благочиния Ивана Абросимова указывалось: «Печальные антихристианские настроения и действия среди юношества: непосещение храма, отрицание таинств церкви, насмешки над согражданами, кто упорно держится церковности». В Цакирском и Харацайском приходах Джидинского благочиния были отмечены случаи «религиозного разложения, особенно в Харацае как центре современной культуры. Появились коммунисты, затем комсомольцы... около них появилось безверие», которое священник Дмитрий Зуйков охарактеризовал как «проявление модного явления - религиозного индифферентизма» 4 .

1 ГАНИИО. Ф. 16. ОП. 1. Д. 1234. Л. 1, 5.

2 ГАЗК. Ф. П-71. ОП. 1. Д. 535. Л. 34.

3 ГАНИИО. Ф. 1. ОП. 1. Д. 1821. Л. 265.

4 ГАЗК. Ф. Р-422. Оп. 1. Д. 35. Л. 49, 58, 127. 
Все вышеизложенное свидетельствует, что антирелигиозная агитация и пропаганда, являясь одним из инструментов государственной политики, представляла собой разнообразие форм и методов, способов и средств, направленных на искоренение религиозного мировоззрения и обрядовых повседневных практик. Это была борьба на идеологическом фронте, борьба за социализм, воспитание человека новой формации, которая должна была привести к сокращению числа верующих, ликвидации церковных институтов и др. На территории Байкальского региона в рассматриваемый период происходило институциональное становление агитационно-пропагандистской деятельности, совершенствовалось ее нормативно-правовое, кадровое и методическое обеспечение. Опыт местных антирелигиозных практик (от штурма и натиска до системной работы) подтверждает правомерность тактических изменений, обусловленных партийно-государственными установками. Однако говорить об эффективности форм и методов антирелигиозной пропаганды довольно сложно, ведь, несмотря на весь комплекс социально-экономических модернизационных мероприятий и административно-репрессивных мер 19201930-х гг., власть не смогла поставить под контроль внутреннюю жизнь верующих, а религиозные традиции и ценности продолжали сохраняться.

\title{
Список литературы
}

Бакаев Ю.Н. 2002. Власть и религия: история отношений (1917-1941). Хабаровск: Изд-во ХГТУ. 199 с.

Готовщик А.С. 2011. Антирелигиозная пропаганда в Восточном Забайкалье в первой половине 1920-х годов. - Гуманитарный вектор. № 3(27). С. 84-88.

Цыремпилова И.С. 2008. Русская православная церковь и государство: история взаимоотношений в 1917-1930-е г2. (на материалах Байкальского региона). Улан-Удэ: ИПК ВСГАКИ. 300 с.

\section{ANTIRELIGIOUS AGITATION AND PROPAGANDA IN 1920s: ITS FORMS, EXPERIENCE AND EFFECTIVENESS (on the materials of the Baikal Region)}

\begin{abstract}
Based on the documents of the state archives of the Republic of Buryatia, Irkutsk Region and Zabaikalsk Region, the article examines formation and development of antireligious agitation and propaganda in 1920s. On the definite examples the article also reveals variety of forms and methods of the activities: from lectures, debates, political meetings, processions, demonstrations, plays and carnivals to antireligious days, weeks, actions, campaigns, etc. The author shows difficulties in organizational and staffing support of antireligious activities.
\end{abstract}

Keywords: antireligious policy, antireligious agitation and propaganda, Baikal Region, church, believers, atheists 